\title{
TYPOLOGY OF REGULATIONS RELATED TO MINORITIES IN THE NATIONAL LEGISLATIONS OF CERTAIN STATES Claudia ANDRIŢOI
}

\author{
"Eftimie Murgu" University, Reşiţa, Romania \\ andritoiclaudia@yahoo.com
}

\begin{abstract}
The international regulations in the filed of minorities settle not only an international standard, but also a set of norms generally accepted by the states in this respect. Like in other domains of human rights, these norms represent a minimum of regulations beyond which one or several states, depending on their concrete situation and the international commitment they assume in the regional or bilateral plane, may apply more comprehensive norms and concepts. Such an approach corresponds also to the distinct situations of diverse minorities in the word: numerous or less numerous, compact or dispersed from the demographic point of view; some have been taken centuries to congregate, others have been formed recently, as a result of migration, whereas others have originated from native populations; some minorities are constituted according to ethnic criteria, others according to linguistic, cultural or religious criteria, and these elements are rarely encountered together.
\end{abstract}

Keywords: minorities, national identity, discrimination, international regulations, assumed obligations, protection, guarantee

\section{Introduction}

The effort of integration into the great family of European democracy includes the necessity to solve first the tensions originated in the matter of national minorities. The individualised treatment of each group, but especially the construction of the national and international frame meant to ensure the defence of human rights may be solved in this bold endeavour. The obligations in relation with the minorities assumed by states in treaties represent only a premise for the setting of an appropriate status of the persons who differ from the majority population by ethnic origin, language or religion. The states preserve a wide liberty of appreciations as regards the legislative or administrative means by which their assumed obligations are to be executed.

The international consecration of this statement is given by the commitment subscribed within the Conference of Security and Cooperation in Europe - C. S. C. E. The final act of al C. S. C. E. signed at Helsinki in 1975 provided a general stipulation, according to which ,the participant states on whose territory national minorities live shall observe the rights of the these minorities' members to equality before the law, shall grant them full opportunities to actually exercise their human rights and fundamental liberties and for this purpose they shall protect their legitimate interests in this respect ". The provision was transferred in similar terms to the documents adopted at the general European reunions of Madrid (1980 -1983) and Vienne (1986-1989).

The guarantee and promotion of the rights granted to national minorities have constituted the object of numerous 
normative acts, for completing and detailing the commitments assumed by the ratification of international documents, such as the Frame Convention for the National Minorities' Protection of the Council of Europe of 1995 (Romania being one of the first states to sign this Convention) or the 1992 Chart of Regional or Minority Languages (ratified by Romania in 2007). Thus, step by step, one has built a complex well-articulated and stable system for national minorities' protection. This system, compatible with the high international standards in the matter, has been built with the direct involvement of minorities and is perfective in time by adequate public policies.

\section{The issues of national minorities in the rule of law}

A more enhanced approach was realised by the document adopted at the Copenhagen Reunion of the Conference for the Human Dimension of the Conference for Security and Cooperation in Europe, which correlated the problems of human rights' observance with the realisation of pluralist democracy and the rule of law. The document comprises important precisions in relation with requirements such as organising free elections, installing representative governance, concordance between states' laws and their obligations regulated by international law. As a new element, we see intervening also the right of persons to associate and create organisations meant to watch over the respect of human rights, bodies that should be granted the possibility of establishing contacts with similar organisations and international organisms. The persons belonging to the national minorities have the right to fully and effectively exercise their human rights and fundamental liberties, without discrimination and in full equality before the law. The participant states shall adopt, if need be, special measures aiming at guaranteeing, for the persons belonging to national minorities, full equality with the other citizens in exercising and benefiting from the human rights and fundamental liberties. "[1].

Furthermore, point 33 of the document institutes the obligation of participant states to protect the ethnic, cultural, linguistic and religious identity of national minorities on their territory and to create conditions meant to promote such identity. They shall take the necessary measures in this respect after adequate consultations and especially after having contacted the organisations or associations of these minorities, according to the decision-making procedure in each state and with the observance of the principles of equality and nondiscrimination compared to the other citizens of the respective participant state. The Copenhagen document condemns any type of discrimination and any persecution for religious and ideological reasons, and underlines the fact that the participant states will take effective measures in order to combat such phenomena, including by the adoption, according to their constitutional system and international obligations assumed, laws necessary for the ensuring of the protection against any act that could constitute an incitation to violence based on national, racial, ethnic or religious discrimination.

The participant states pledge themselves to acknowledge the rights of any person to effective recourse, and will endeavour to recognise, according the national legislation, the rights of the interested persons or groups of persons to file complaints against the acts of discrimination and to support such complaints. Finally, the state shall take into account the possibility to join international instruments related to discrimination and shall guarantee they fully comply with the obligations contained in these instruments, including those stipulating the presentation of periodical reports and will examine the possibility of adapting the international mechanisms allowing the particular states and private persons to send communications to international organisms regarding the acts of discrimination.

The C. S. C. E. Experts' Reunion, specially 
summoned to deal with the issues of minorities, adopted a report reaffirming that the human rights and fundamental liberties constitute the foundation of the protection and promotion of the rights of persons belonging to minority groups. The report consecrates one more the rights mentioned in the Copenhagen document and insists on the action modalities for their implementation: the participation of the persons belonging to minorities to public life and consultations, special measures for these persons, on non-discriminatory bases in relation with other citizens and with the consideration of the history and territorial particulars related to minorities. It includes more detailed provisions in relation with the contacts of persons from minorities and their access to information. Moreover, it reiterates recommendations regarding the condemnation of acts of hate, antiSemitism, xenophobia, discrimination, and the states' obligation to struggle for the promotion of tolerance, understanding, equal opportunities and good relations among persons of different origin.

The activity of international human rights organisms are necessarily correlated with the domestic action of governmental or non-governmental organisations and their contacts with the national institutions interested in the matter, according to the available information. According to our data, at present there are in the world national institutions for the promotion and protection of human rights in more than 30 states. The geographic distribution of these institutions is relatively proportional, they are present in Europe, as well as in Africa or on the American continent. As for the main types, we may list the French system, encountered on the territory of the former French colonies in Africa (Togo, Morocco, Tunisia etc.), the British model found in the Commonwealth countries too, and the American type (including in Canada, the Philippines etc.). These institutions can be categorised into human rights commissions, Ombudsman and specialised national institutions.
When we examine the significance of international law as regards the minorities' status, we remark that international law settles most of the times the rights related to a minimum protection standard. A series of fundamental aspects related to the regime of minorities and the role within the state of different communities constituted by ethnic, language or religion criteria, as well as the modality of ensuring the political representation of these communities, involves the estimation of a complex of factors the states are in no circumstance willing to leave to the appreciation of others. Granting or failing to grant local, territorial or personal autonomy, identifying the groups of persons different by ethnic, religious or linguistic aspects as minorities, nationalities or constituting nations of the state, establishing higher education institutions in the minorities' language are acts that are part of the appreciation area circumscribed to national sovereignty. [2].

As long as the norms of international law remain limited to the imposition of minimum standards for minorities' protection, the domestic legislation is expected to offer concrete solutions meant to ensure the political integration of the persons belonging to minorities and guarantees them the preservation, manifestation and development of their ethnic, linguistic or religious identity.

\section{The approach of national minorities' rights in France}

According to its political traditions instituted during the 1789-1792 Revolution, France has long denied the existence of national minorities on its own territory. This attitude was manifested in the most obvious manner on the occasion of the ratification of the International Pact related to the civil and political rights, when France formulated a reserve related to art. 27, claiming that there are no minorities on its territory, only linguistic particularities. Art. 2 of the 1958 French Constitution stipulated the indivisibility of the French Republic and implicitly the existence of a homogenous national, of the idea of nation- 
state. According to the data corresponding to the ' $80 \mathrm{~s}$, France had seven minority populations, without taking into account the persons who effectively speak a regional language; consequently around 5 million persons, a tenth of the population, was concerned with issues specific to minorities. According to recent data, the situation appears largely changed, in the sense that along with the French ethnic group another 7 ethnic groups and 11 minorities are mentioned, representing around $40 \%$ of the country's total population [7].

The Occitan area represents the most important and complex Latin-origin entity. Comprising a third of the territory and a fourth of the population, Occitania represents the largest nation state in Europe spread in the south of France, and several valleys in Italy and Spain. The global population of this territory is of 10.5 million inhabitants, of whom more that a half can speak one of the Occitan idioms. The use of these idioms recorded a withdrawal in the post-war period and the majority of this population ignore their own identity. In the opinion of Jacques Ressaire, the good progress of the French state's decolonisation depends on the future of Occitan nationalism, as the French state should be turned into a federation, according to its regional structures. The Occitan originality is well marked from the point of view of ethnic, ethnicpsychological, political and cultural origin, not to mention the demographic, economic and social perspective. The absence of national unity, the permeability of natural frontiers in the east and south, the mentality of the population could be the factors necessary for the justification of an effective decentralisation, in other words of internal federalism [3].

The Corsica Island is situated at the frontier of two indigenous languages, one in the north, of Italian type (CismontaneCismuntanu), and another in the south, of the Sardinian type (Ultramuntanu). Despite the fascist temptations during the Second
World War, most of the Corsican population exhibited anti-Italian feelings [6]. The problems of the Basques and Catalonians are raised in France in a less severe manner than in Spain, where this minority fights against the state and the Castilian predominance. In the political plane, we must remark that the E.T.A. terrorism, violently manifested in the Basque Country, province belonging to Spain, does not have an equivalent in the small French Basque region.

An extremely interesting situation is represented by Alsace; it had been part of the German world more than a thousand years and represented a dispute matter between France and Germany during the French-Prussian war of 1870-1871 and the two world wars. After 1871, Germanophone Alsace and Lorrain became territories of the German Empire, and the Law of June $9^{\text {th }} 1871$ established "for ever" the common property of the 25 federal states. 50,000 Alsatians and Lorrainers emigrated then to France and Algeria. The autonomist tendency has rapidly developed and the constitutional law of 31 May 1911 turned Alsace and Lorraine into a federal state with 3 parliament members in the Bundestag. An Assembly of two Chambers was constituted in Strasbourg. Toward the end of the First World War, on November $9^{\text {th }} 1918$ they proclaimed the independence of the Neutral Republic of Strasbourg. This precipitated the entry of France troops into Alsace, however the French assimilation policies provoked extremely powerful autonomist claims. With a dramatic history, Alsace inherited a particular mental situation. According to Emile Baas, "to assume Alsace was a fatality much too heavy to bear". The need for security and inner peace provoked the Alsatians' rupture with the past, in order to get totally integrated into the French and the francophone universe ". In the opinion of the quoted authors, what is frapping for Alsatians is this permanent will of the inhabitants to affirm themselves as more French than the French of Ile de France. 
Despite the complexity of the sociological and psychological complexity of Alsace, in time Alsatians started again to discover their origins, first by establishing certain centres meant to defend the Alsatian language and culture, and then, later on, in the political plane, by the apparition of three autonomist parties. The pressures to intimidate the revival of Alsatian autonomy took not long to appear, but the Alsatian autonomists inscribed their actions within the context of Rhenanian and European perspective, turning autonomy into the first stage of ,Europe of the hundred flags "[5].

France has encouraged jus loci as regards citizenship, in contrast with the emigration countries, which consecrate the privilege of jus sanguinis, in order to allow the citizens' children to preserve their parents' citizenship. Although the immigrants originating from some of the former French colonies spoke the language as means of international circulation, the assimilations project has failed because of the huge cultural gap between the French culture and that of immigrants, before the well-shaped ethnicity „of their large number and the organization and family groups and ethnic communities preserving their own cultural identity and the relations with the origin country. At the same time, the assimilationist project started to look less and less legitimate, and the old idea according to which France has a civilising mission started to fade. Concomitantly, the respect for cultural differences increased along with the awareness of the fact that it is necessary to renounce to the own cultural identity in order to finally obtain the French citizenship, „exchange” seen as more and more difficult to accept, from the moral perspective, especially by today's immigrants[4].

In France, the immigration issue is still debated in terms of ,integration", a phase that should be understood more than a mere euphemism of the former ,assimilation” notion (although the social dimension is stressed more than the cultural one). In fact, French culture, although undergoing a process of transformation as a result of the processes of globalisation, European integration and adoption of foreign traditions, especially by the French youth.

\section{Conclusions}

The life of any national minority, its identity and welfare cannot be the fruit of a particular commitment, because, no matter how well- protected minorities may be from the legislative perspective, and no matter how high the autonomy granted to it could be, it cannot be efficient as long as it would present an insular character. It is only in a state which, in its entirety, ensures all its citizens the certainty of the irreversibility of a democratic system and economic prosperity that the protection of the individual rights could be fully achieved, irrespective of the individuals' ethnic origin.

The protection of cultural identity and representation of the interests of ethnic communities members are fundamental obligations of any democratic state, and what's more, they represent national interests. However, the attempts of cultural isolation or ethnic purification are beneficial neither for the community nor for the state, and each state taken separately has the duty to act in order to make society attractive for all its citizens, either members of the minority groups or majority citizens.

\section{References}

[1] Bălan, Marius Nicolae, International law and the status of minorities. Relations between domestic law and international law on this issue (in Romanian), Cluj-Napoca, 1998 (University "Babeş-Bolyai"), (PhD thesis)

[2] Diaconu, Ion, Minorites. Status. Prospects (in Romanian), Bucharest, Romanian Institute for Human Rights, 1996.

[3] Diaconu, Ion, Human rights (in Romanian), Bucharest, Institute for Human Rights, 1993. 
[4] Duculescu, Victor, Călinoiu, Constanţa, Duculescu, Georgeta, Compared constitutional law (in Romanian), Bucharest, Ed. Lumina Lex, 1996.

[5] Henri Giordan, Les minorities en Europe. Droits linguistiques et Droits de l'Homme, Paris, Editions Kime, 1992.

[6] Năstase, Adrian, Conflict of minorities-historic, cultural, political or economic causes (in Romanian), in: "Pro Democraţia", vol. 1, no. 1, October 1994

[7] Zlătescu, Victor Dan, Moroianu, Zlătescu Irina, Human Rights in Action (in Romanian), Romanian Institute for Human Rights, Bucharest, 1994. 